\title{
Keseimbangan Biomassa dan Pemanenan Energi Pada Pengolahan Limbah Cair Kelapa Sawit
}

\section{Biomass Balance and Energy Harvesting in Palm Oil Mills Wastewater Treatment}

\author{
TAJUDDIN BANTACUT", ANIS YULI FITRIANI \\ Departmen Teknologi Industri Pertanian, Institut Pertanian Bogor \\ Kampus IPB Darmaga Bogor \\ Email: bantacuttajuddin@gmail.com
}

\begin{abstract}
Processing of palm oil mills effluent (POME) consumes considerable amounts of energy. POME contains organic materials that can be converted into methane gas as an energy source. This study aimed at the development of energy self-sufficiency concept in the POME processing by harvesting the energy contained in the generated biogas. The development of this concept was carried out by analyzing the Chemical Oxygen Demand (COD) balance in POME processing, assessing energy potential, calculating energy requirements, and constructing an energy-independent POME treatment model. The results of this study showed that the electrical energy that can be generated from the processing of POME was 70 $\mathrm{kW}$ per hour, while the energy requirement is $39 \mathrm{kWh}$. The energy potential can meet the energy needs, with an energy surplus of $30 \mathrm{~kW}$ per hour. This study explained that the processing of POME can be selfsufficient by degrading organic matter into methane gas using Upflow Anaerobic Sludge Blanket Reactor (UASBR).
\end{abstract}

Keywords: methane, POME, COD model, closed system, electricity, UASBR.

\section{ABSTRAK}

Pengolahan limbah cair kelapa sawit menggunakan energi dalam jumlah besar. Limbah cair kelapa sawit mengandung bahan organik yang dapat dikonversi menjadi gas metana sebagai sumber energi. Penelitian ini bertujuan untuk mengembangkan konsep mandiri energi pada pengolahan limbah cair kelapa sawit dengan memanen energi yang terdapat dalam biogas yang terbentuk selama pengolahan limbah cair. Pengembangan konsep ini dilakukan dengan menganalisis keseimbangan COD di dalam limbah cair, mengkaji potensi energi, menghitung kebutuhan energi, dan membangun pengolahan limbah cair kelapa sawit mandiri energi. Hasil studi ini menunjukkan bahwa energi listrik yang dapat dihasilkan dari proses pengolahan limbah cair kelapa sawit adalah sebesar $70 \mathrm{~kW}$ per jam, sedangkan kebutuhan energi adalah sebesar $39 \mathrm{kWh}$. Potensi energi tersebut dapat memenuhi kebutuhan energi, bahkan terdapat surplus energi sebesar $30 \mathrm{~kW}$ per jam. Studi ini menjelaskan bahwa pengolahan limbah cair kelapa sawit dapat mandiri energi dengan mendegradasi bahan organik menjadi gas metana menggunakan Upflow Anaerobic Sludge Blanket Reactor (UASBR).

Kata kunci: gas metana, limbah cair sawit, model COD, sistem tertutup, listrik, UASBR

\section{PENDAHULUAN}

\subsection{Latar Belakang}

Proses produksi minyak sawit dari tandan buah segar (TBS) kelapa sawit menghasilkan limbah cair sebanyak $0,5-0,75 \mathrm{~m}^{3}$ per ton TBS yang diolah. Limbah ini harus diolah sebelum digelontorkan ke lingkungan. Jumlah energi yang dibutuhkan untuk pengolahan limbah cair adalah $0,26-2,5 \mathrm{kWh}$ per $\mathrm{m}^{3}$. Pabrik kelapa sawit di Indonesia rata-rata memiliki kapasitas 45-120 ton TBS per jam, sehingga membutuhkan energi listrik sampai $225 \mathrm{kWh}$ untuk pengolahan limbah cairnya. Kebutuhan energi ini akan terus meningkat dengan bertambahnya jumlah limbah yang dihasilkan dari proses produksi crude palm oil (CPO) yang juga terus meningkat. Selama ini pengolahan limbah cair menggunakan energi listrik, sehingga dapat mengakibatkan penambahan biaya yang dikeluarkan oleh perusahaan ${ }^{(1,2)}$. Upaya untuk mengurangi konsumsi energi listrik dan perlindungan lingkungan perlu dilakukan sehingga mengurangi konsumsi sumberdaya dan biaya lingkungan. Salah satu solusi dari masalah tersebut yaitu pengolahan limbah secara anaerobik untuk menghasilkan energi.

Proses pengolahan limbah dengan cara anaerobik akan mendegradasi bahan organik menghasilkan biogas. Salah satu teknologi anaerobik yang biasa digunakan adalah upflow anaerobic sludge blanket reactor (UASBR) $)^{(3,4)}$. 
Limbah cair kelapa sawit merupakan suspensi koloid terdiri atas 95-96\% air, 0,6-0,7\% minyak, dan $4-5 \%$ padatan total. Karbohidrat, lipid, dan protein adalah bahan organik yang dapat digunakan sebagai substrat untuk menghasilkan energi pada pengolahan limbah cair kelapa sawit $^{(5,6)}$. Dalam setiap meter kubik limbah cair kelapa sawit menghasilkan 20 sampai $28 \mathrm{~m}^{3}$ biogas yang mengandung $45-75 \%$ gas metana $^{(7)}$. Bantacut dan Pasaribu ${ }^{(8)}$ menghitung limbah cair dari pabrik kelapa sawit kapasitas 60 ton TBS per jam sebanyak $17,55 \mathrm{~m}^{3}$ dengan ratarata kandungan COD sekitar $51.000 \mathrm{mg} / \mathrm{L}$ berpotensi menghasilkan energi sebanyak 1.275 kW. Gas metana dihasilkan dari degradasi bahan organik dapat diketahui dari nilai COD dalam limbah cair saat proses pengolahan sehingga energi yang dihasilkan dapat dihitung. Limbah cair kelapa sawit memiliki kandungan COD sekitar $15.000-100.000 \mathrm{mg} / \mathrm{L}^{(9,10)}$. Setiap kg COD pada bahan organik yang dapat didegradasi berpotensi menghasilkan energi sebanyak 3,86 $\mathrm{kWh}^{(11,12)}$

Berdasarkan fakta tersebut, diperlukan suatu analisis potensi pemanenan energi pada proses pengelolaan limbah cair kelapa sawit. Analisis dilakukan untuk mengkaji potensi energi dari pemanenan yang digunakan untuk memenuhi kebutuhan energi pada proses pengolahan limbah cair kelapa sawit. Hasil analisis diharapkan dapat menjadi dasar pengembangan pengolahan limbah cair kelapa sawit yang mandiri energi.

\subsection{Tujuan Penelitian}

Tujuan penelitian ini adalah untuk mengembangkan konsep mandiri energi pada pengolahan limbah cair kelapa sawit dengan memanfaatkan energi yang terbentuk dari pengolahan limbah cair kelapa sawit dalam UASBR.

\section{BAHAN DAN METODE}

Untuk mencapai tujuan tersebut, langkahlangkah utama yang dilakukan adalah:

a. Mempelajari pengolahan limbah cair kelapa sawit menggunakan UASBR.

b. Menganalisis keseimbangan COD dalam pengolahan limbah cair kelapa sawit.

c. Menghitung potensi energi yang dihasilkan dari pengolahan limbah cair kelapa sawit.

d. Menghitung kebutuhan energi dalam pengolahan limbah cair kelapa sawit.

e. Membangun konsep pengolahan limbah cair kelapa sawit yang mandiri energi.

\subsection{Kerangka Pemikiran}

Proses pengolahan limbah cair kelapa sawit secara anaerobik akan menghasilkan energi berupa gas metana yang selama ini terbuang dapat dipanen sebagai sumber energi dalam pengolahan limbah. Perhitungan dilakukan pada keseimbangan COD dan energi untuk mengetahui kecukupan energi. Jika energi yang dapat dipanen melebihi energi yang diperlukan, maka sistem pengolahan limbah dapat dikembangkan menjadi proses mandiri energi. Sebaliknya, jika energi yang dapat diperoleh lebih kecil dari kebutuhan pengolahan limbah, maka pengolahan memerlukan pasokan energi dari luar sistem pengolahan limbah tersebut.

\subsection{Pengumpulan Data}

Data dikumpulkan dari sumber sekunder yaitu jurnal, skripsi, tesis, disertasi, dan buku yang mencakup karakteristik limbah cair kelapa sawit, proses pengolahan limbah cair kelapa sawit, penghilangan COD pada pengolahan limbah cair kelapa sawit, dan kebutuhan energi untuk pengolahan limbah cair kelapa sawit.

\subsection{Batasan Sistem}

Proses pengolahan limbah cair kelapa sawit terdiri atas kompartemen utama yaitu screening, oil separation tank, cooling tower, equalization tank, UASBR (sludge bed, sludge blanket, dan gas separator), dan aerobic pond. Umpan masuk adalah limbah cair yang dihasilkan dari pabrik yang memiliki kapasitas TBS 60 ton per jam dan memiliki nilai COD sebesar $51.000 \mathrm{mg} / \mathrm{L}^{(9,10)}$. Menurut Bantacut dan Pasaribu ${ }^{(8)}$ limbah tersebut berjumlah $17.55 \mathrm{~m}^{3}$ per jam yang berasal dari proses perebusan $(32,5 \%)$ dan pemurnian $(67,5 \%)$. Parameter utama adalah degradasi COD pada limbah cair menjadi gas metana dan hasil samping adalah nilai COD removal pada screening, equalization tank, UASBR, dan aerobic pond.

\subsection{Deskripsi Model Keseimbangan COD}

Model keseimbangan COD dikembangkan dengan asumsi bahwa pengolahan limbah cair terdiri dari beberapa kompartemen yang menghubungkan input $(\mathrm{I})$, produk $(\mathrm{P})$, dan hasil samping (W) yang seimbang pada setiap kompartemennya (Gambar 1). Model keseimbangan COD yang dikembangkan menggambarkan tahapan proses pengolahan limbah cair dengan adanya perincian pada tahap UASBR. Keseimbangan COD diperoleh dari input sama dengan output.

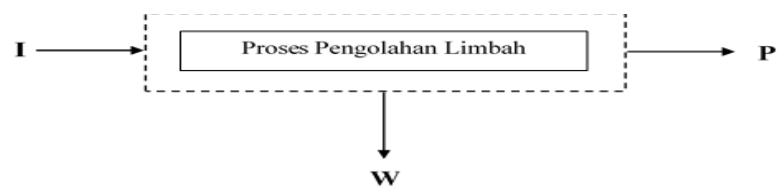

Gambar 1. Model umum keseimbangan COD 
Keterangan: $\mathrm{I}=$ Input; $\mathrm{P}=$ Produk; $\mathrm{W}=$ Hasil samping

Persamaan 1 yang menggambarkan keseimbangan COD adalah:

$\mathrm{I}=\mathrm{P}+\mathrm{W}$ dan Effisiensi $(\mathrm{a})=\frac{p}{I}$

\subsection{Potensi Energi Berdasarkan COD}

Berdasarkan model keseimbangan COD dalam proses pengolahan limbah maka didapatkan volume gas metana. Volume gas metana dapat dihitung dengan Persamaan $2^{(13)}$ :

Volume gas metana $\left(\mathrm{m}^{3}\right)=$

Nilai $\operatorname{COD}(\mathrm{kg}) \times R \times\left(\frac{273+T}{P \times K C O D \times 1000}\right)$

Keterangan :

$\mathrm{P} \quad=$ tekanan atmosfer (1 $\mathrm{atm})$

$\mathrm{K}_{\mathrm{COD}}=\mathrm{COD}$ dalam $1 \mathrm{~mol} \mathrm{CH}_{4}(0,064 \mathrm{~kg} \mathrm{COD}$ $\mathrm{CH}_{4} \mathrm{~mol}^{-1}$ )

$\mathrm{R}=$ Konstanta gas $\left(0,08206 \mathrm{~atm} \mathrm{~L} \mathrm{~mol}^{-1} \mathrm{~K}^{-1}\right)$

$\mathrm{T}=$ Suhu operasi reaktor $\left({ }^{\circ} \mathrm{C}\right)$

Potensi energi dapat dihitung dengan Persamaan 3.

$$
\begin{aligned}
\text { Potensi energi }(\mathrm{kJ})= & \text { Volume gas }\left(\mathrm{m}^{3}\right) \times \text { Nilai } \\
& \text { kalor }(\mathrm{kJ} / \mathrm{kg}) \times \text { Massa jenis } \\
& \text { gas }\left(\mathrm{kg} / \mathrm{m}^{3}\right) \ldots \ldots \ldots \ldots \ldots \ldots
\end{aligned}
$$

Keterangan: Nilai kalor didapatkan dari sumber literatur dan COD dari perhitungan keseimbangan COD

Massa jenis metana $=0,648 \mathrm{~kg} / \mathrm{m}^{3(13)}$

Nilai kalor $=56.000 \mathrm{~kJ}^{(14)}$

\subsection{Pemodelan Keseimbangan COD}

Model keseimbangan COD pada proses pengolahan limbah cair kelapa sawit memiliki satu peubah bebas $\left(I_{1}\right)$ dan 14 peubah tidak bebas $\left(W_{1}, W_{4}, W_{5}, W_{6}, W_{81}, W_{82}, X_{1}\right.$ sampai $X_{7}$, dan $\mathrm{P}_{7}$ ) (Gambar 2). Terdapat 8 kompartemen yang menggambarkan pengolahan limbah cair kelapa sawit, dua diantaranya dapat diabaikan yaitu separation tank dan cooling tower (kompartemen 2 dan 3) karena tidak ada nilai COD yang keluar dari sistem. Oleh karena itu diperlukan 12 persamaan untuk dapat menghitung nilai dari peubah tidak bebas.

Proses screening partikel yang dibuang adalah serat, cangkang, sebagian sludge, dan lain-lain. Alat yang digunakan adalah rotary screening. Oil separation tank berfungsi untuk mengutip sisa minyak pada limbah cair kelapa sawit. Pemisahan minyak dilakukan dengan perbedaan densitas antara air dan minyak ${ }^{(15)}$.
Tahap pendinginan diperlukan karena limbah cair kelapa sawit memiliki suhu yang tinggi, yaitu 80$90^{\circ} \mathrm{C}$ sehingga pada saat limbah akan masuk ke tahap pendinginan suhu berkisar $60-70^{\circ} \mathrm{C}^{(16)}$. Pada tahap pendinginan digunakan cooling tower guna menurunkan suhu sekitar $10-25^{\circ} \mathrm{C}^{(17,18)}$. Equalization tank bertujuan untuk menyiapkan umpan limbah cair sebelum masuk ke UASBR. Proses pada equalization tank ditambahkan $\mathrm{CaO}$ untuk menaikkan $\mathrm{pH}$ dari 4-5 ke 6-8 dan proses pengadukan menggunakan blower ${ }^{(16,19)}$. Tahap ini dilakukan pemeriksaan untuk mengetahui suhu limbah cair sebelum masuk ke UASBR yang harus sesuai kondisi mesofilik yaitu suhu $35-37^{\circ} \mathrm{C}^{(20)}$.

Komponen utama dari UASBR dalam pendegradasian bahan organik yaitu sludge bed, sludge blanket, dan gas separator. Sludge bed terletak pada bagian bawah sebagai wadah sludge yang dihasilkan dari proses anaerobik, sedangkan sludge blanket adalah tempat pendegradasian bahan organik yang terdapat pada bagian tengah. Gas separator terletak pada bagian atas reaktor yang berfungsi untuk tempat keluarnya biogas yang terbentuk dari proses anaerobik $^{(21)}$. Tahap terakhir adalah aerobic pond dengan waktu pengolahan selama 60 jam dan menggunakan blower. Tahap aerobic dilakukan dengan proses aerasi dengan tujuan untuk menghilangkan sisa-sisa bahan organik yang masih terdapat di dalam limbah cair ${ }^{(22,23)}$.

\section{Persamaan Keseimbangan COD:}

Kompartemen 1: $I_{1}-W_{1}-X_{1}=0$.

Kompartemen 4: $\mathrm{X}_{1}-\mathrm{W}_{4}-\mathrm{X}_{4}=0$

Kompartemen 5: $X_{4}-W_{5}-X_{5}=0$

Kompartemen 6: $\mathrm{X}_{5}-\mathrm{W}_{6}-\mathrm{X}_{6}=0$.

Kompartemen 7: $\mathrm{X}_{6}-\mathrm{P}_{7}-\mathrm{X}_{7}=0$.

Kompartemen 8: $X_{7}-W_{81}-W_{82}=0$

Persamaan efisiensi:

COD pada sludge dari proses screening $\left(\mathrm{a}_{1}\right)$

$\mathrm{a} 1=\frac{\mathrm{W} 1}{\mathrm{I} 1}=\frac{\text { COD pada sludge dari screening }}{\text { COD pada influent }}$

Menurut Chaisri et al. ${ }^{(16)}$, saat proses screening di dalam pengolahan limbah cair kelapa sawit akan menghilangkan sludge dengan nilai COD sebesar $24,2 \%$ dari total COD pada limbah cair, sehingga nilai $a_{1}$ adalah 0,242.

COD pada limbah cair yang teroksidasi dari equalization tank $\left(\mathrm{a}_{2}\right)$

$\mathrm{a} 2=\frac{\mathrm{W} 4}{\mathrm{X} 1}=\frac{\text { COD pada limbah cair yang teroksidasi dari equalization tank }}{\ldots}$ 


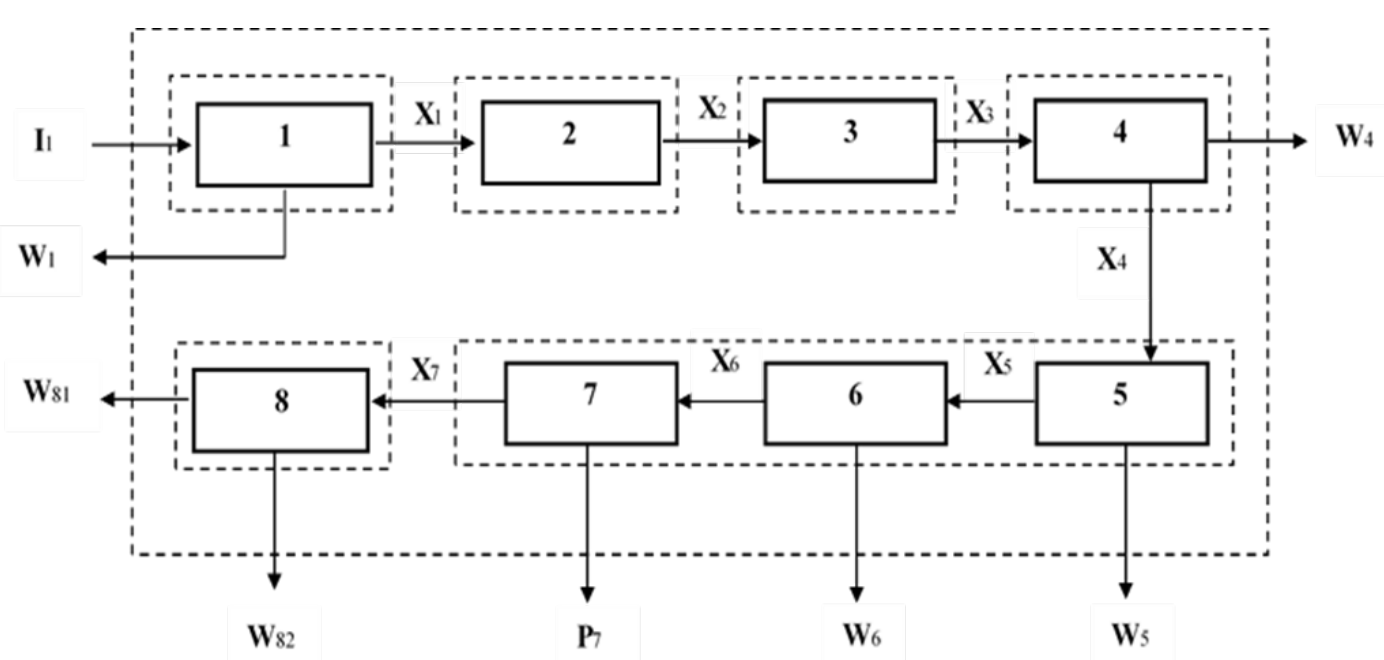

Gambar 2. Rancangan model keseimbangan chemical oxygen demand (COD)

Keterangan simbol pada Tabel 1.

Tabel 1. Keterangan pada rancangan model keseimbangan chemical oxygen demand (COD)

\begin{tabular}{|c|c|}
\hline Kompartemen & Keterangan (Proses) \\
\hline 1 & Screening \\
\hline 2 & Oil separation tank \\
\hline 3 & Cooling tower \\
\hline 4 & Equalization tank \\
\hline 5 & Sludge bed \\
\hline 6 & Sludge blanket \\
\hline 7 & Gas separator \\
\hline 8 & Aerobic pond \\
\hline Input & Output \\
\hline $\mathrm{I}_{1}=$ COD pada influent & $\begin{array}{l}\mathrm{P}_{7}=\text { COD pada limbah cair yang dapat dikonversi } \\
\text { menjadi gas metana }\end{array}$ \\
\hline Waste & Aliran Internal \\
\hline $\begin{array}{l}\mathrm{W}_{1}=\mathrm{COD} \text { pada sludge dari } \\
\text { screening }\end{array}$ & $\mathrm{X}_{1}=$ COD pada limbah cair dari screening \\
\hline $\begin{array}{l}W_{4}=C O D \text { pada limbah cair yang } \\
\text { teroksidasi dari equalization tank }\end{array}$ & $\mathrm{X}_{2}=$ COD pada limbah cair dari oil separation \\
\hline $\mathrm{W}_{5}=$ COD pada sludge dari UASBR & $\mathrm{X}_{3}=\mathrm{COD}$ pada limbah cair dari cooling tower \\
\hline $\begin{array}{l}W_{6}=C O D \text { pada limbah cair untuk } \\
\text { menghilangkan sulfat }\end{array}$ & $\mathrm{X}_{4}=\mathrm{COD}$ pada limbah cair dari equalization tank \\
\hline $\begin{array}{l}W_{81}=C O D \text { pada limbah cair yang } \\
\text { teroksidasi dari aerobic pond }\end{array}$ & $\mathrm{X}_{5}=$ COD pada limbah cair dari sludge bed \\
\hline $\mathrm{W}_{82}=\mathrm{COD}$ pada effluent & $\mathrm{X}_{6}=\mathrm{COD}$ pada limbah cair dari sludge blanket \\
\hline & $\mathrm{X}_{7}=\mathrm{COD}$ pada limbah cair dari gas separator \\
\hline
\end{tabular}

Pada tahap equalization tank terjadi oksidasi bahan organik yang diketahui dari nilai COD removal pada limbah cair saat proses equalisasi. COD tersebut yaitu sebesar $30 \%$ dari total COD limbah cair yang masuk ${ }^{(24)}$, maka nilai $\mathrm{a}_{2}$ adalah 0,30 .

COD pada sludge dari UASBR $\left(a_{3}\right)$

$\mathrm{a} 3=\frac{\mathrm{W} 5}{\mathrm{X} 4}=\frac{\text { COD pada sludge dari UASBR }}{\text { COD pada limbah cair dari equalization tank }}$
Berdasarkan perhitungan keseimbangan COD di dalam UASBR didapatkan bahwa nilai COD pada limbah cair yang masuk ke UASBR yaitu $474,91 \mathrm{~kg}$. Proses anaerobik dalam UASBR menghasilkan sludge dengan nilai COD sebesar $55,56 \mathrm{~kg}$ sehingga COD pada sludge sebesar $11,7 \%$ dari total COD pada limbah cair. Oleh karena itu, nilai $a_{3}$ adalah 0,117 . 
sulfat $\left(a_{4}\right)$

COD pada limbah cair untuk menghilangkan

$\mathrm{a} 4=\frac{\mathrm{W} 6}{\mathrm{X} 5}=\frac{\text { COD pada limbah cair untuk menghilangkan sulfat }}{\text { COD pada limbah cair dari sludge bed }}$.

Berdasarkan perhitungan keseimbangan COD di dalam UASBR didapatkan bahwa COD pada limbah cair dari sludge bed yaitu $419,93 \mathrm{~kg}$. Adanya bahan organik untuk menghilangkan sulfat yaitu dengan COD sebesar $0,04 \mathrm{~kg}$ sehingga COD pada bahan organik dalam limbah cair untuk menghilangkan sulfat sebesar $0,01 \%$. Oleh karena itu, nilai efisiensi $\mathrm{a}_{4}$ adalah 0,0001.

COD pada limbah cair yang dapat dikonversi menjadi gas metana di dalam UASBR pada gas separator $\left(a_{5}\right)$

$\mathrm{a} 5=\frac{\mathrm{P} 7}{\mathrm{X} 6}=\frac{\text { COD pada limbah cair yang dapat dikonversi menjadi gas metana }}{\text { COD pada limbah cair dari sludge blanket }}$

Berdasarkan perhitungan keseimbangan COD di dalam UASBR didapatkan bahwa COD pada limbah cair dari sludge blanket yaitu 419,3 $\mathrm{kg}$. Pada UASBR terjadi pendegradasian bahan organik yang digunakan sebagai substrat untuk menghasilkan gas metana. Bahan organik yang dapat terdegradasi pada limbah cair setara dengan COD sebesar $335,44 \mathrm{~kg}$ sehingga jumlah COD yang dapat diubah menjadi gas metana sebesar $80 \%$. Oleh karena itu, nilai $a_{5}$ adalah 0,8 .

COD pada limbah cair yang teroksidasi pada tahap aerobic pond $\left(\mathrm{a}_{6}\right)$.

$\mathrm{a} 6=\frac{\mathrm{W} 81}{\mathrm{X} 7}=\frac{\text { COD pada limbah cair yang teroksidasi dari aerobic pond }}{\text { COD pada limbah cair dari gas separator }}$.

Proses pengolahan limbah cair kelapa sawit secara aerobik dengan hanya memberikan oksigen ke dalam limbah dengan waktu 60 jam menyebabkan COD removal sebesar $98 \%$ dari total COD yang masuk pada aerobic pond ${ }^{(22,23)}$. Oleh karena itu, maka efisiensi $\mathrm{a}_{6}$ adalah sebesar 0,98 .

Berdasarkan uraian di atas, faktor efisiensi dapat dilihat pada Tabel 2.
Tabel 2. Nilai efisiensi keseimbangan chemical oxygen demand (COD)

\begin{tabular}{crl}
\hline Simbol & \multicolumn{1}{c}{ Nilai } & Referensi \\
\hline $\mathrm{a}_{1}$ & 0,242 & $(16)$ \\
$\mathrm{a}_{2}$ & 0,30 & $(24)$ \\
$\mathrm{a}_{3}$ & 0,117 & $\begin{array}{l}\text { Perhitungan } \\
\text { penulis }\end{array}$ \\
$\mathrm{a}_{4}$ & 0,0001 & $\begin{array}{l}\text { Perhitungan } \\
\text { penulis }\end{array}$ \\
$\mathrm{a}_{5}$ & 0,8 & $\begin{array}{l}\text { Perhitungan } \\
\text { penulis } \\
\mathrm{a}_{6}\end{array}$ \\
\hline
\end{tabular}

\section{HASIL DAN PEMBAHASAN}

\subsection{Hasil Perhitungan Keseimbangan COD}

Perhitungan keseimbangan dilakukan berdasarkan pada pengolahan limbah cair dari pabrik kelapa sawit kapasitas pengolahan 60 ton TBS per jam yang berjumlah $17,55 \mathrm{~m}^{3}$ dengan kandungan $\operatorname{COD} 51.000 \mathrm{mg} / \mathrm{L}^{(8,9,10)}$. Hasil perhitungan menunjukkan bahwa proses pengolahan limbah cair kelapa sawit mengkonversi bahan organik sebagai substrat menjadi gas metana. Sekitar $56 \%$ dari total COD dalam limbah cair dapat didegradasi menjadi gas metana ${ }^{(25)}$. Namun demikian, hasil perhitungan menunjukkan bahwa COD yang dapat didegradasi menjadi gas metana hanya sebesar $335,44 \mathrm{~kg}$ atau $37 \%$ dari COD total. Perbedaan ini disebabkan karena perhitungan dilakukan dengan adanya treatment pendahuluan sebelum pengolahan anaerobik sehingga didapatkan hasil lebih kecil. Sebagian bahan organik telah hilang pada tahapan proses tersebut (Gambar 3). Perhitungan keseimbangan menghasilkan COD pada effluent sebesar $1,67 \mathrm{~kg}$ per $17,55 \mathrm{~m}^{3}$ atau $95 \mathrm{mg} / \mathrm{L}$ sehingga memenuhi baku mutu limbah cair kelapa sawit, yaitu maksimal $350 \mathrm{mg} / \mathrm{L}^{(26)}$. Hal ini menggambarkan bahwa proses pengolahan limbah cair kelapa sawit yang ada telah menghasilkan efluen dengan konsentrasi di bawah baku mutu. 


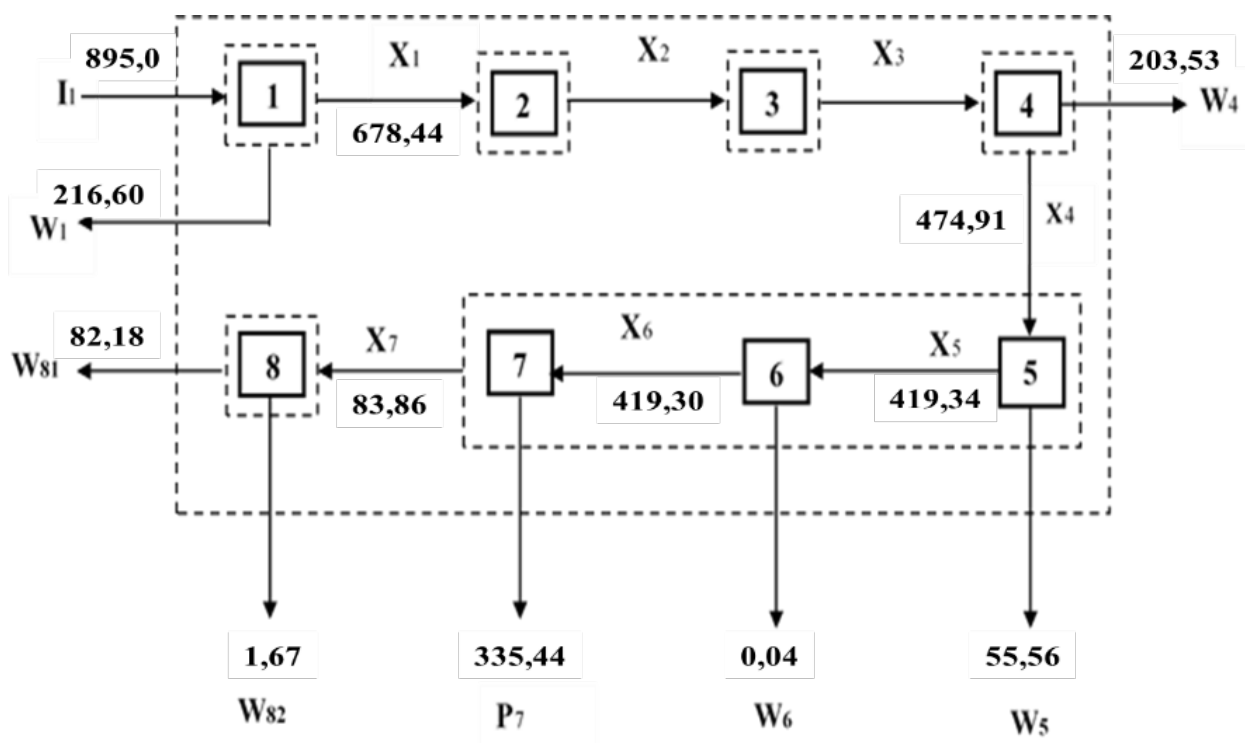

Gambar 3. Aliran chemical oxygen demand (COD) pada model keseimbangan (kg/hari)

Tabel 3. Perhitungan energi listrik yang dapat dibangkitkan

\begin{tabular}{|c|c|c|c|}
\hline Parameter & Satuan & Jumlah & Sumber \\
\hline \multicolumn{4}{|c|}{ Perhitungan potensi } \\
\hline Kapasitas air limbah pabrik & $\mathrm{m}^{3} / \mathrm{jam}$ & 17,55 & (8) \\
\hline Nilai COD pada limbah cair & $\mathrm{mg} / \mathrm{L}$ & 51.000 & $(9,10)$ \\
\hline $\begin{array}{l}\text { COD pada limbah cair yang } \\
\text { masuk ke UASBR }\end{array}$ & $\mathrm{Kg} / \mathrm{jam}$ & 474,91 & $\begin{array}{l}\text { Perhitungan Penulis } \\
\text { dengan keseimbangan } \\
\text { COD }\end{array}$ \\
\hline Efisiensi UASBR removal COD & $\%$ & 82,4 & $(19,27)$ \\
\hline COD removal & $\mathrm{Kg} / \mathrm{jam}$ & 391,32 & \\
\hline Volume gas metana terbentuk & $\mathrm{m}^{3} / \mathrm{jam}$ & 133,44 & \\
\hline Massa jenis metana & $\mathrm{Kg} / \mathrm{m}^{3}$ & 0,648 & (13) \\
\hline Massa gas metana terbentuk & $\mathrm{Kg} / \mathrm{jam}$ & 86,46 & \\
\hline Nilai kalor metana & $\begin{array}{l}\mathrm{MJJ} / \mathrm{kg} \\
\text { metana }\end{array}$ & 56 & $(14)$ \\
\hline Total potensi energi & MJ/jam & 4.842 & \\
\hline \multicolumn{4}{|c|}{ Steam yang dihasilkan } \\
\hline $\begin{array}{l}\text { Kebutuhan panas untuk } \\
\text { memproduksi } 1 \mathrm{Kg} \text { Uap pada } \\
\text { 10,4 Bar dan suhu jenuh }\end{array}$ & $\mathrm{KJ} / \mathrm{Kg}$ & 2.779 & Tabel uap \\
\hline Total steam & $\mathrm{Kg} / \mathrm{jam}$ & 1.742 & \\
\hline Efisiensi boiler & $\%$ & 80 & (28) \\
\hline Steam aktual & $\mathrm{Kg} / \mathrm{jam}$ & 1.393 & \\
\hline \multicolumn{4}{|c|}{ Total energi yang dihasilkan } \\
\hline \multirow{4}{*}{$\begin{array}{l}\text { Konversi steam pada single } \\
\text { stage convertion turbine } \\
\text { Total Energi Listrik } \\
\text { Kebutuhan energi listrik pada } \\
\text { pengolahan limbah cair } \\
\text { Surplus energi }\end{array}$} & $\mathrm{Kg} / \mathrm{kW}$ & 20 & (8) \\
\hline & kW/jam & 70 & \\
\hline & kWh & 39 & Tabel 4 \\
\hline & kW/jam & 30 & \\
\hline
\end{tabular}




\subsection{Pemanenan Energi pada Pengolahan Limbah Cair Kelapa Sawit}

Banyak penelitian yang telah dilakukan tetapi fokus pada upaya penanganan POME sehingga buangannya memenuhi kriteria limbah cair $^{(38) .}$ Pembentukan dan pemanfaatan energi tidak menjadi tujuan ${ }^{(37,39)}$. Penelitian ini selain berorientasi pada penanganan limbah juga secara simultan memanfaatkan energi yang dihasilkan sebagai bagian terpadu dari penanganan POME.

Konsentrasi umpan limbah cair saat penggunaan UASBR adalah 15,5 sampai $65 \mathrm{~kg}$ COD per $\mathrm{m}^{3}$ dalam keadaan suhu mesofilik dan hydraulic retention time (HRT) selama 9 jam. Kondisi tersebut dapat mendegradasi bahan organik sebanyak $82,4 \%$ yang diketahui dari nilai COD. Penggunaan UASBR memiliki keuntungan yaitu memiliki efisiensi degradasi bahan organik yang relatif tinggi, produksi gas metana tinggi, serta hemat energi, dan mudah dioperasikan ${ }^{(5,19)}$.

Gas metana yang dihasilkan dari UASBR diubah menjadi energi listrik untuk memasok kebutuhan energi pada proses pengolahan limbah cair kelapa sawit. Perhitungan menggunakan model menghasilkan volume gas metana sebanyak $133,44 \mathrm{~m}^{3}$ per jam yang setara dengan $335,44 \mathrm{~kg}$ COD. Volume ini tidak jauh berbeda dengan penelitian dari Borja \& Banks $^{(27)}$, yakni bahan organik yang dapat didegradasi menjadi gas metana dengan rendemen $0,395 \quad \mathrm{CH}_{4} \quad \mathrm{~m}^{3} / \mathrm{kg}$ COD dengan menggunakan UASBR atau setara dengan $132,5 \mathrm{~m}^{3}$ per jam. Dengan demikian dapat disimpulkan bahwa persamaan yang digunakan untuk perhitungan keseimbangan COD memiliki akurasi yang baik.

Gas metana yang dihasilkan dimanfaatkan sebagai bahan bakar untuk pemanasan biogas fired boiler pada tekanan 10,4 bar yang memiliki efisiensi $80 \%{ }^{(28)}$. Uap yang dihasilkan dialirkan ke turbin untuk memutar generator sehingga membangkitkan energi listrik. Penggunaan single stage convertion turbine dapat mengkonversi setiap $20 \mathrm{~kg}$ uap panas menjadi energi listrik sebesar $1 \mathrm{~kW}^{(8)}$. Perhitungan pada Tabel 3 menunjukkan bahwa energi listrik yang dapat dihasilkan adalah sebesar $70 \mathrm{~kW}$ per jam.

Kebutuhan energi pada setiap pabrik berbeda-beda karena alat yang digunakan sesuai dengan karakteristik dan kapasitas limbah cair. Penggunaan energi listrik tersebut umumnya untuk pompa dan blower (Tabel 4). Total kebutuhan energi listrik pada proses pengolahan limbah cair kelapa sawit dengan kapasitas 60 ton TBS per jam adalah 56\% dari total energi yang dapat dihasilkan. Nilai ini sesuai dengan kebutuhan energi pengolahan limbah cair yaitu rata-rata sebesar 0,26-2,5 kWh per $\mathrm{m}^{3}$ limbah cair ${ }^{(1)}$.

Tabel 4 Perhitungan kebutuhan energi pada pengolahan limbah cair

\begin{tabular}{|c|c|c|c|c|c|}
\hline No & Treatment Unit & Alat & $\begin{array}{l}\text { Power } \\
\text { (kW) }\end{array}$ & $\begin{array}{l}\text { Energi } \\
(\mathrm{kWh})\end{array}$ & Sumber \\
\hline \multirow{2}{*}{1} & \multirow{2}{*}{ Screening } & $\begin{array}{l}\text { Transfer pump } \\
\text { limbah cair }\end{array}$ & 2,2 & 2,2 & (31) \\
\hline & & rotary screening & 0,73 & 0,73 & (32) \\
\hline \multirow{2}{*}{2} & \multirow{2}{*}{$\begin{array}{l}\text { Oil Separation } \\
\text { tank }\end{array}$} & $\begin{array}{l}\text { transfer pump } \\
\text { limbah cair }\end{array}$ & 2,2 & 2,2 & (31) \\
\hline & & transfer oil pump & 0,18 & 0,18 & (33) \\
\hline \multirow{3}{*}{3} & \multirow{3}{*}{ Cooling tower } & $\begin{array}{l}\text { Transfer pump } \\
\text { limbah cair }\end{array}$ & 2,2 & 2,2 & $(31)$ \\
\hline & & fan power & 5 & 5 & $(17,18,34)$ \\
\hline & & spray pump power & 1 & 1 & $(17,18,34)$ \\
\hline 4 & $\begin{array}{l}\text { Equalization } \\
\text { tank }\end{array}$ & Blower & 3,7 & 3,7 & (35) \\
\hline 5 & UASBR & $\begin{array}{l}\text { Pump transfer } \\
\text { limbah cair }\end{array}$ & 2,2 & 2,2 & (31) \\
\hline \multirow[t]{2}{*}{6} & Aerobic pond & Blower & 22 & 22 & (36) \\
\hline & & & Energi & 39 & \\
\hline
\end{tabular}

Berdasarkan perhitungan, pengolahan limbah cair kelapa sawit dapat memenuhi kebutuhan energi listrik secara mandiri sehingga dapat menerapkan sistem tertutup, yakni tidak memerlukan input energi dari lingkungan atau luar sistem ${ }^{(29)}$. Selain dapat memenuhi kebutuhan energi sendiri, proses pengolahan limbah cair dari pabrik kelapa sawit kapasitas pabrik 60 ton TBS per jam menghasilkan surplus listrik sebesar $30 \mathrm{~kW}$ per 
jam yang setara dengan $260 \mathrm{MW}$ per tahun. Kelebihan energi listrik yang dihasil dapat digunakan untuk cadangan energi pada pabrik atau dapat dijual dalam bentuk listrik. Menurut Bantacut dan Novitasari ${ }^{(30)}$, konsumsi listrik minimum rumah tangga adalah $680 \mathrm{kWh}$ per kapita per tahun dengan asumsi setiap rumah terdiri dari 4-5 kapita. Berdasarkan konsumsi listrik per rumah tersebut, maka kelebihan energi listrik setara dengan kebutuhan listrik sekitar 64-96 rumah sepanjang tahun.

\subsection{Sistem Tertutup pada Pengolahan Limbah Cair Kelapa Sawit}

Pengembangan sistem tertutup ditujukan untuk meningkatkan nilai dari hasil samping dan limbah sebagai bagian terpadu dari proses produksi dan atau penanganan limbah ${ }^{(8,30)}$. Integrasi ini dimaksudkan untuk menghindari investasi ganda karena pemisahan sistem produksi secara mandiri dengan pemanfaatan dan atau penangan limbah secara mandiri pula.

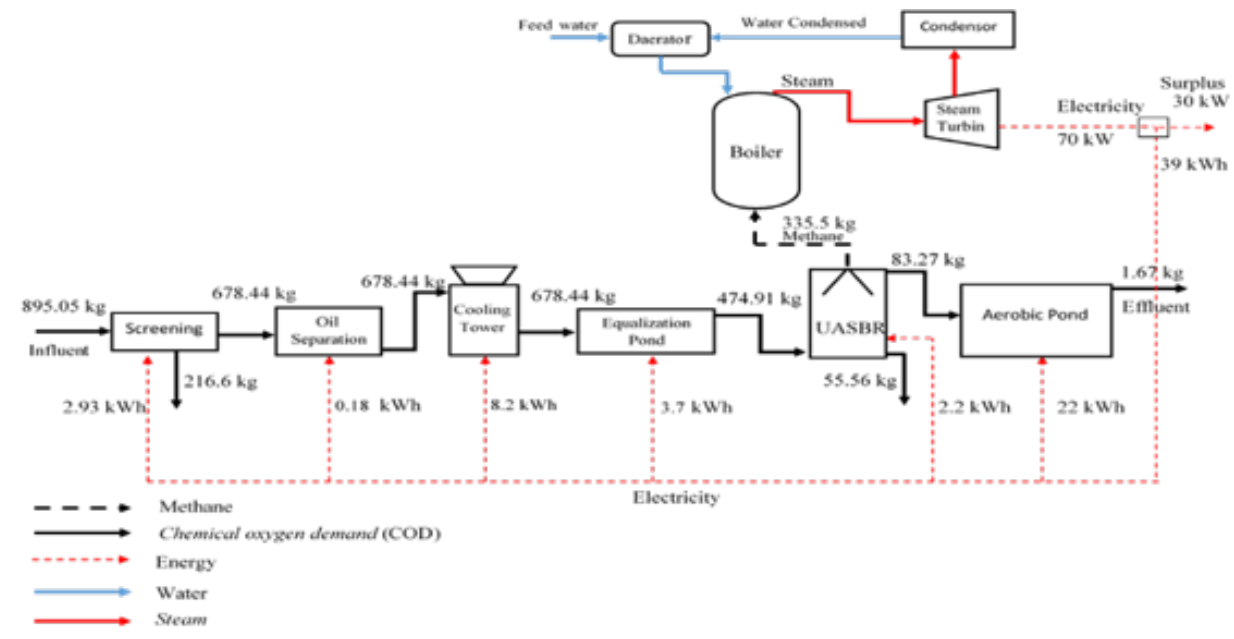

Gambar 4. Sistem tertutup pada pengolahan limbah cair kelapa sawit

Pengolahan limbah cair kelapa sawit dengan cara anaerobik menghasilkan gas metana yang dapat diubah menjadi energi listrik. Jumlah energi yang dihasilkan digunakan kembali sebagai input pada proses pengolahan limbah cair kelapa sawit. Perolehan energi dari pemanfaatan gas metana, melebihi energi yang diperlukan sehingga dapat dikembangkan sistem tertutup pada proses pengolahan limbah cair kelapa sawit (Gambar 4). Pembakaran gas metana untuk memanaskan air di dalam boiler, menghasilkan uap panas yang digunakan untuk memutar generator pada turbin sehingga dihasilkan energi listrik untuk menjalankan screening, pompa, cooling tower, dan blower. Pada turbin terdapat sisa uap panas yang dikondensasi dapat digunakan kembali sebagai umpan boiler.

\section{KESIMPULAN}

Model keseimbangan

COD menggambarkan proses rinci pengolahan limbah cair kelapa sawit. Limbah cair pabrik kelapa sawit dengan kapasitas 60 ton TBS per jam mengandung COD sebanyak 335,44 kg yang dapat dikonversi menjadi metana sebanyak $133,44 \mathrm{~m}^{3}$ per jam. Metana sebanyak itu dapat menghasilkan energi listrik sebesar 70
kW per jam melebihi kebutuhan energi untuk proses pengolahan limbah cair kelapa sawit sebesar $39 \mathrm{kWh}$. Oleh karena itu, proses pengolahan limbah cair dapat mandiri energi, bahkan berpotensi surplus energi sebesar 30 kW per jam.

\section{DAFTAR PUSTAKA}

1. Tao, X.C. (2014). Energy consumption in wastewater treatment plants in China. [Conference paper]. [May 2012 in conference World Congress on Water, Climate and Energy at Dublin, Ireland]. [diunduh pada 31 Agustus 2017]. Tersedia pada:https://www.researchgate.net/publica tion/266146909.

2. Ahmed, Y., Yaakob, Z., Akhtar, P., \& Sopian K. (2015). Production of biogas and performance evaluation of axisting treatment processes in palm oil mill effluent (POME). Journal of Renewable and Sustainable Energy Reviews, 42, 1260-1278.

3. Demirel, B. \& Scherer, P. (2008). The roles of acetotrophic and hydrogenotrophic methanogens during anaerobic conversion 
of biomass to methane a review. Rev Environ Sci Biotechnol,7, 173-190.

4. Wong, Y.S., Kadir, M.O.A.B, \& Teng, T.T. (2009). Biological kinetics evaluation of anaerobic stabilization pond treathment of palm oil mill effluent. Bioresource Technology, 100 (21), 4969-4975.

5. Borja, R. \& Banks, C.J. (1994). Treatment of palm oil mill effluent by upflow anaerobic filtration. Journal of Chem Technol Biotechnol., 61, 103-109.

6. Wu, T.Y., Mohammad, A., Jahim, J. \& Anuar N. (2007). Palm oil mill effluent (POME) treatment and bioresources recovery using ultrafiltration membrane: effect of pressure on membrane fouling. Biochemical Engineering Journal, 35(9), 309-317.

7. Ma, A.N. (1999). Treatment of palm oil mill effluent. Oil palm and environment: Malaysia perspective. Malaysia Oil Palm Growers'Council, p. 277.

8. Bantacut, T. \& Pasaribu, H. (2015). Aliran tertutup massa dan potensi energi pada produksi CPO. Jurnal Teknologi Industri Pertanian, 25(3), 215-226.

9. Khemkhao, M., Nuntakumjorn, B., Techkarnjanaruk, S. (2011). Effect of chitosan on UASB treating POME during a transition from mesophilic to thermophilic conditions. Bioresource Technology, 102(7), 4674-4681.

10. Ma, A.N. (2000). Environment management for the palm oil industry. Palm Oil Develop. 30,1-10.

11. Shizas, I. Bagley, D.M. (2004). Experimental determination of energy content of unknown organics in municipal wastewater streams. Journal of Energy Engineering, 130(2),45-53.

12. Shoener, B.D., Bradley, I.M., Cusicka, R.D. and Guest, J.S. (2014). Energy positive domestic wastewater treatment: The roles of anaerobic and phototrophic technologies. Environmental Science: Processes \& Impacts, 16, 1204-1222.

13. Annamalia, K. \& Puri, I.K. (2002). Advanced Thermodynamics, CRC Series in Computational Mechanics and Applied Analysis. Amerika Serikat (US): CSC Press.

14. Lam, L. \& Lee, K. (2011). Renewable and sustainable bioenergies production from palm oil mill effluent (POME): Win-win strategies toward better environmental protection. Journal of Biotechnology, 29, 124-141.

15. Tabassum, S., Zhang, Y., Zhang, Z. (2015). An integrated method for palm oil mill effluent (POME) treatment for achieving zero liquid discharge-A pilot study. Journal of Cleaner Production, 95, 148-155.

16. Chaisri, R., Boonsawang, P., Prasertsan, P., Chaiprapat, S. (2007). Effect of organic loading rate on methane and volatile fatty acids productions from anaerobic reatment of palm oil mill effluent in UASB and UFAF reactors. Songklanakarin J. Sci.Technol. 29(2), 311-323.

17. Paping, L. (1995). Energiebesparing door schone koelers, Proceedings of Watersymposion. Breda (NL): (23-47).

18. [ECDGJRC] European Commission Directorate-General Joint Research Centre. 2000. Integrated Pollution Prevention and Control Reference Document on the application of Best Available Techniques to Industrial Cooling Systems. Institute for prospective Technological Studies (Seville) Technologies for Sustainable Development European IPPC Bureau. Spanyol (ES): ECDGJRC.

19. Ahmad, A., Ghufran, R., Abd Wahid, Z. (2011). Role of calcium oxide in sludge granulation and methanogenesis for the treatment of palm oil mill effluent using UASB reactor. Journal of Hazard Material. 98, 40-48.

20. Tchobanoglus, G., Burton, F., Stense, H. (2003). Wastewater Engineering: Treatment and Reuse, $4^{\text {th }}$ Edition, New York (US): McGraw Hill Companies Inc.

21. Yasar, A., Ahmad, N., Chaudhry, M.N. \& Khan, A. (2007). Sludge granulation and efficiency of phase separator in UASB reactor treating combined industrial effluent. Journal of Environmental Sciences, 19(5), 553-558.

22. Chou, K.W., Tan, S.W., Morad, N., Tow, T.T., Kadir, M.O.A. \& Ismail, N. (2016). Aerobic post-treatment of different anaerobically digested palm oil mill effluent (POME). International Journal of Environmental Science and Development, 7(7), 511-515.

23. Wang, L.K., Hung, Y.T., Lo, H.H. \& Yapijakis, C. (2004). Handbook of Industry 
and Hazardous Wastes Treatment. Texas (US): CRC Press.

24. Ahmad, D., Aziz, M., Vijayaraghavan, K. 2007. Aerobic treatment of palm oil mill effluent. Journal of Environmental Management, 82, 24-31.

25. Damayanti, A., Ujang, Z., Salim, M.R., Olsson, G., Sulaiman, A.Z. (2010). Respirometric analysis of activated sludge model from palm oil mill effluent. Journal of Bioresource Technology, 101, 144-149.

26. [KMNLH] Kementrian Lingkungan Hidup. 2014. Salinan Peraturan Keputusan Menteri Negara Lingkungan Hidup Nomor 5 Tahun 2014 tentang Baku mutu air limbah. Jakarta (ID): KMNLH.

27. Borja, R. \& Banks, C.J. (1994). Anaerobic digestion of palm oil mill effluent using an up flow anaerobic sludge blanket reactor. Journal of Biomass and Bioenergy, 6(5), 381-389.

28. Yingjian L.I., Qi, Q.I.U., Xiangzhu' H.E. \& Jiezhi, L.I. (2011). Energy use project and conversion efficiency analysis on biogas produced in breweries. World Renewable Energy Congress - Sweden 8-13 May 2011. Unduh pada tanggal 19 Juni 2018 dari:

http://citeseerx.ist.psu.edu/viewdoc/downlo ad?doi=10.1.1.452.56\&rep=rep1\&type=pdf

29. Cangel, Y.A. \& Boles, M.A. (2002). Thermodynamics: An Engineering Approach $4^{\text {th }}$ Edition in SI Units. Singapore (SI): McGraw-Hill.

30. Bantacut, T. \& Novitasari, D. (2016). Energy and water self-sufficiency assessment of the white sugar production process in Indonesia using a complex mass balance model. Journal of Cleaner Production, 126,478-492.

31. Alibaba.com. Pompa ZWL centrifugal sewage portable wastewater treatment pump for remote settlement. [Internet]. [Waktu unduh 2017 Agustus 5]. Tersedia pada: https://www.alibaba.com/productdetail/ZWL-centrifugal-sewage-portable
wastewaterPump_1602963465.html?spm= a2700.7724838.2017115.37.Ekyb98.

32. Vodatech.net. Waste Water Technology, Rotary screen is used for continuous separation of solid pollution in waste water. [Internet]. [Diunduh pada: 2017 Agustus 5]. Tersedia pada: http://www.vodatech.net/en/stahnout/8

33. Foxenviro. Oil-water separator pump. [Internet]. [Diunduh pada: 2017 Agustus 5]. Tersedia pada: http://www.foxenviro.com.au/specifications IFXP1000-diaphragm-pump-spec.pdf.

34. Coopers, U. L. 1998. BREF-document for cooling systems order of Eurovent, the European Committee of Air Handling and Refrigeration Equipment Manufacturers. Report number: 61350027.

35. Chuanfan.com. Centrifugal Blower - Turbo Blower. [Internet]. [Diunduh pada: 2017 Agustus 5]. Tersedia pada:http://www.chuanfan.com/03-tb.html.

36. Larsson V. 2011. Energy Savings with a New Aeration and Control System in a Mid-Size Swedish Wastewater Treatment Plant (Online Book). Swedia (SE): Uppsala University.

37. Yacob, S., Shirai Y., Hassan, M.A., Wakisaka, M. \& Subash, S. (2006). Startup operation of semi research facilities. commercial closed anaerobic digester for palm oil mill effluent treatment. Process Biochemistry, 41: 962-964.

38. Rupani, P.F., Singh, R.P.,Ibrahim, M.H. \& Esa, N. (2010). Review of Current Palm Oil Mill Effluent (POME) Treatment Methods: Vermicomposting as a Sustainable Practice. World Applied Sciences Journal, 10(10): 1190-1201.

39. WU, T.Y., Mohammad, A.W., Jahim, J.M. \& Anuar, N,. (2009). A holistic approach to managing palm oil mill effluent (POME): Biotechnological advances in the sustainable reuse of POME. Biotechnology Advances, 27: 40-52 